\title{
MODERN APPROACHES TO THE SCREENING ASSESSMENT OF THE DEGREE OF THE RISK OF PRENOSOLOGICAL DISORDERS IN THE STATE OF MENTAL HEALTH OF SCHOOL-AGE PUPILS IN THE CONTEXT OF ANALYSIS OF BEHAVIORAL ASPECTS OF PUBLIC HEALTH
}

DOI: 10.36740/WLek202105123

\author{
Ihor V. Serheta, Olha Yu. Bratkova, Oksana V. Dyakova, Oksana B. Dudarenko, Inna L. Drezhenkova, \\ Larysa M. Vakolyuk, Tetiana V. Lobastova \\ NATIONAL PIROGOV MEMORIAL MEDICAL UNIVERSITY, VINNYTSIA, UKRAINE
}

\begin{abstract}
The aim: Scientific substantiation of the method of screening assessment of the degree of risk of prenosological changes in the state of the mental health of school-age pupils in the context of the analysis of behavioral aspects of public health.

Materials and methods: The level of neuroticism of young women and men was assessed based on the use of the Eysenck personality questionnaire, the level of state, trait and school anxiety - according to the Spielberger State-Trait Personality inventory and Phillips school anxiety questionnaire, the level of emotional burnout - based on the use Boiko questionnaire, the level of aggressive manifestations - according to data Bassa-Darkness questionnaire, the level of depression - based on the use data of Zung self-rating depression scale.

Results: The method of screening the degree of risk of prenosological changes in the mental health of school-age pupils involves determining the degree of expression of neuroticism, state, trait and school anxiety, emotional burnout, aggression and depression. The obtained data are evaluated in standardized scores, which are used to calculate the integrated indicator of mental health and the integrated indicator of dynamic changes in mental health, on the basis of which the person is classified as minimal, low, moderate or high risk of mental health abnormalities.

Conclusions: The proposed method is a simple and easy to use, highly informative tool for identifying adverse prenosological changes in mental health of school-age pupils in the context of analyzing the behavioral aspects of public health.
\end{abstract}

KEY WORDS: pupils, mental health, prenosological changes, screening assessment

Wiad Lek. 2021;74(5):1169-1173

\section{INTRODUCTION}

The formation of the public health system taking place in Ukraine involves the development and implementation of both strategic in content and tactical in nature medical and social measures aimed at protecting, preserving and strengthening the health of the population as a whole and its specific groups in particular and, above all, pupils and students. Moreover, its main task is, on the one hand, to determine the degree of expression of health, the effect, on the other hand, to establish the features of adverse effects of socially significant factors of stress on the health of the population or its individual contingents, scientific substantiation of recommendations to prevent deviations in the state of human health and public health [1-7].

In this context, special attention should be paid to the problems of intersectoral cooperation in the field of public health, the development of scientific bases for the prevention of both infectious and non-infectious diseases, the introduction of behavioral methods to influence the formation of health of people of all ages, the state of health of school-age pupils. Moreover, given the significant deterioration in the mental health of pupils, which is observed recently, it is extremely important to find tools that can effectively adjust the processes of formation of mental characteristics of young women and young men to prevent the development of prenosological and pathological changes $[1,4,9,10]$. Therefore, a necessary and mandatory component of research that considers this problem is the development and evaluation of programs and measures aimed at diagnosing, preventing and eliminating the first, according to the time of appearance, mental disorders.

\section{THE AIM}

The purpose of the study is to scientifically substantiate the method of screening assessment of the degree of risk of prenosological changes in the mental health of schoolage pupils in the context of analysis of behavioral aspects of public health. 


\section{MATERIALS AND METHODS}

Scientific research was carried out on the basis of a number of secondary schools in Vinnytsya and National Pirogov Memorial Medical University. To develop a method of screening to assess the risk of prenosological changes in the mental health of school-age pupils were taken into account the most significant, criterion from a social, educational and professional standpoint, personality traits, the level of expression of which was determined by using modern informative psychodiagnostic techniques. This approach provided an opportunity to develop an adequate and accessible approach to a comprehensive assessment of the mental state of pupils and identify the risk of both prenosological changes in their mental health and the formation of individual manifestations of mental pathology. The methodological basis of the carried out scientific work fully corresponded to existing bioethical norms, requirements of the existing legislation and international standards, which is confirmed by the conclusion of the committee on bioethics of the higher education institution.

Thus, the level of neuroticism of young women and young men was assessed based on the use of the Eysenck personality questionnaire, the level of state, trait and school anxiety - according to the Spielberger State-Trait Personality inventory and Phillips school anxiety personality questionnaire, the level of emotional burnout - based on the use Boiko personality questionnaire, the level of aggressive personality manifestations - according to data Bassa-Darkness personality questionnaire, the level of depression - based on the use data of Zung self-rating depression scale. [11].

The obtained results were subjected to statistical processing using procedures of descriptive statistics and correlation analysis based on the use of a standard package of statistical analysis programs "Statistica 6.1" (licensed № BXXR901E245722FA).

In addition, the method of screening assessment of the degree of risk of prenosological changes in the mental health of pupils was based on the method of expert assessments using the methods of group examination followed by ranking and pairwise comparison [12].

\section{RESULTS}

The method of screening the degree of risk of prenosological changes in the mental health of school-age pupils involves the calculation of integrated indicators that determine the mental health of young women and young men, both qualitative and quantitative its dynamic changes over time, as well as the degree of risk the emergence of prenosological changes in the leading signs of mental state among pupils. An important feature is the fact that the proposed method makes it possible to determine the level of mental health of an individual, allows you to objectively assess its dynamic changes due to various environmental factors and social living conditions, and, therefore, timely pay attention to the emergence the first, original in its content, changes in the state of mental health, which are prenosological in nature and are precursors to the formation of mental maladaptation.

A distinctive feature of the screening assessment of the risk of prenosological changes in the mental health of school-age pupils is its significant effectiveness in determining the feasibility of psychohygienic logical correction of existing mental disorders that occur at the pre-disease level and should be eliminated by early diagnosis. It should be noted that the developed methodology is extremely accessible and easy to interpretation, such as can be used by experienced doctors and ordinary school nurses and school psychologists.

At the initial stage of application of the proposed technique on the basis of personal questionnaires and test methods determines the level of personality traits of young women and young men, namely: indicators of the level of neuroticism, state, trait and school anxiety, emotional burnout, aggression and predisposition to depression $[8,9]$. Studies of this content are carried out during the annual preventive medical examinations at the beginning of the school year, i.e. during the period when all processes of psychophysiological content are activated and the initial changes in mental health are most clearly and adequately diagnosed. Subsequently, based on the use of the proposed scoring scale of the screening assessment of the risk of prenosological changes in the mental health of schoolchildren determine the standardized number of points obtained separately for each of the studied indicators (Table I).

To classify pupils according to risk categories, taking into account the degree of probability of mental health disorders, identifying individuals with prenosological changes and pathological manifestations, as well as determining the nature of interventions to be recommended, using formula (1), which is developed using specially scales for scoring the level of development of criterion features of pupils' personality on the basis of using methods of group examination with subsequent ranking and pairwise comparison, calculate the integrated indicator of assessment of mental state (IIAMS) of young women and young men:

IIAMS $=0,152 \times \mathrm{N}+0,237 \times$ Anx $+0,205 \times$ SAnx + $0,191 \times \mathrm{EB}+0,095 \times \mathrm{Agr}+0,210 \times \mathrm{D}$

where $\mathrm{N}-$ the level of neuroticism; Anx - the level of anxiety; SAnx - the level of school anxiety; EB - the level of emotional burnout; Agr - the level of expression of aggressive manifestations of personality; D - the level of the development of depression.

According to the value of the calculated IIAMS, the studied pupils should be assigned to one of the 4 categories that are defined, namely to the categories: with a minimum (from 1.00 to 1.75 points), low (from 1.76 to 2.50 points), moderate (from 2.51 to 3.25 points) or high (from 2.26 to 4.00 points) risk of prenosological changes in mental health.

Finally, to assess the qualitative and quantitative dynamic changes in the mental health of a particular person, as well as to assess the effectiveness of psychoprophylactic and psychohygienic methods of mental correction by formula (2) 
Table I. Scoring scale for screening the degree of risk of prenosological changes in the mental health of school-age pupils

\begin{tabular}{|c|c|c|c|}
\hline Indicators & $\begin{array}{l}\text { Research } \\
\text { methodology }\end{array}$ & $\begin{array}{l}\text { Components of screening assessment } \\
\text { and the degree of their expression }\end{array}$ & $\begin{array}{l}\text { Num-ber } \\
\text { of balls }\end{array}$ \\
\hline \multirow{5}{*}{$\begin{array}{l}\text { The level of } \\
\text { neuroticism }\end{array}$} & \multirow{5}{*}{$\begin{array}{l}\text { Eysenck's } \\
\text { personal } \\
\text { questionnaire }\end{array}$} & \multicolumn{2}{|l|}{ The level of neuroticism (emotional instability): } \\
\hline & & high emotional stability (up to 10 points) & 1 \\
\hline & & moderate emotional stability (11-14 points) & 2 \\
\hline & & high emotional instability (15-18 points) & 3 \\
\hline & & very high emotional instability (19-24 points) & 4 \\
\hline \multirow{5}{*}{$\begin{array}{l}\text { The level of } \\
\text { anxiety }\end{array}$} & \multirow{5}{*}{$\begin{array}{l}\text { Spielberger's } \\
\text { state-trait } \\
\text { personality } \\
\text { questionnaire }\end{array}$} & The level of state and trait anxiety: & \\
\hline & & low state (up to 30 points) and low trait (up to 30 points) anxiety & 1 \\
\hline & & $\begin{array}{l}\text { low state (up to } 30 \text { points) and moderate trait (31-44 points) anxiety } \\
\text { moderate state ( } 31-44 \text { points) and low trait (up to } 30 \text { points) anxiety } \\
\text { moderate state ( } 31-44 \text { points) and moderate trait ( } 31-44 \text { points) anxiety }\end{array}$ & 2 \\
\hline & & $\begin{array}{l}\text { low state (up to } 30 \text { points) and high trait (over } 45 \text { points) anxiety } \\
\text { moderate state ( } 31-44 \text { points) and high trait (over } 45 \text { points) anxiety } \\
\text { high state (over } 45 \text { points) and low trait (up to } 30 \text { points) anxiety } \\
\text { high state (over } 45 \text { points) and moderate trait ( } 31-44 \text { points) anxiety }\end{array}$ & 3 \\
\hline & & high state (over 45 points) and high personal (over 45 points) anxiety & 4 \\
\hline \multirow{5}{*}{$\begin{array}{l}\text { The level of } \\
\text { school anxiety }\end{array}$} & \multirow{5}{*}{$\begin{array}{l}\text { Phillips school } \\
\text { anxiety } \\
\text { personality } \\
\text { questionnaire }\end{array}$} & The level of school anxiety and its symptoms: & \\
\hline & & low general anxiety (up to 11 points) & 1 \\
\hline & & $\begin{array}{l}\text { moderate general anxiety (12-16 points), the level of symptoms that form it, low or moderate: } \\
\text { moderate general anxiety (12-16 points), the level of symptoms that form it, low or moderate: the } \\
\text { experience of social stress (up to } 8 \text { points), frustration with the need to succeed (up to } 9 \text { points), } \\
\text { fear of self-expression (up to } 4 \text { points), fear of the situation of testing knowledge (up to } 4 \text { points), } \\
\text { fear of not meeting the expectations of others (up to } 3 \text { points), low physiological resistance (up to } \\
\quad 3 \text { points), problems in relationships with teachers (up to } 5 \text { points). }\end{array}$ & 2 \\
\hline & & $\begin{array}{l}\text { moderate general anxiety (12-16 points), more than three of the symptoms that form it have a } \\
\text { high level: the experience of social stress ( } 9-11 \text { points), frustration of the need to succeed (10-13 } \\
\text { points), fear of self-expression } 6 \text { points), fear of the situation of testing knowledge (5-6 points), } \\
\text { fear of not meeting the expectations of others ( } 4-5 \text { points), low physiological resistance (4-5 } \\
\text { points), problems in relationships with teachers (6-8 points) }\end{array}$ & 3 \\
\hline & & high general anxiety (17-22 points) & 4 \\
\hline \multirow{5}{*}{$\begin{array}{l}\text { The level of } \\
\text { emotional } \\
\text { burnout }\end{array}$} & \multirow{5}{*}{$\begin{array}{l}\text { Boiko's } \\
\text { personality } \\
\text { questionnaire }\end{array}$} & The level of expression of the phases of development of emotional burnout (stress, resistance, ex & laustion): \\
\hline & & $\begin{array}{l}\text { all phases are unformed (up to } 36 \text { points) } \\
\text { one of the phases at the stage of formation ( } 37-60 \text { points) and two unformed phases (up to } 36 \\
\text { points) }\end{array}$ & 1 \\
\hline & & $\begin{array}{l}\text { one unformed phase (up to } 36 \text { points) and two phases at the stage of formation (37-60 points) } \\
\text { two unformed phases (up to } 36 \text { points) and one formed phase (over } 61 \text { points) } \\
\text { all phases at the stage of formation ( } 37-60 \text { points) }\end{array}$ & 2 \\
\hline & & $\begin{array}{l}\text { one unformed phase (up to } 36 \text { points), one phase at the stage of formation (37-60 points) and } \\
\text { one formed phase (over } 61 \text { points) } \\
\text { two phases at the stage of formation ( } 37-60 \text { points) and one phase formed (over } 61 \text { points) } \\
\text { one unformed phase (up to } 36 \text { points) and two formed phases (over } 61 \text { points) }\end{array}$ & 3 \\
\hline & & $\begin{array}{l}\text { one phase at the stage of formation ( } 37-60 \text { points) and two phases formed (over } 61 \text { points) } \\
\text { all phases are formed (more than } 61 \text { points) }\end{array}$ & 4 \\
\hline \multirow{5}{*}{$\begin{array}{l}\text { The level of } \\
\text { aggressive } \\
\text { manifestations } \\
\text { of personality }\end{array}$} & \multirow{5}{*}{$\begin{array}{c}\text { Bassa-Darkness } \\
\text { personality } \\
\text { questionnaire }\end{array}$} & $\begin{array}{c}\text { Level of indicators of aggression (physical, verbal and indirect aggression, negativism, irritation, } \\
\text { feelings of resentment and guilt): }\end{array}$ & uspicion, \\
\hline & & $\begin{array}{c}\text { low level of all indicators (up to } 55 \text { points), but a high level of one of them is possible (over } 55 \\
\text { points) }\end{array}$ & 1 \\
\hline & & from two to four indicators have high levels (over 55 points) & 2 \\
\hline & & from five to seven indicators have high levels (over 55 points) & 3 \\
\hline & & high level of all indicators (over 55 points) & 4 \\
\hline \multirow{5}{*}{$\begin{array}{l}\text { The level } \\
\text { predisposition } \\
\text { to the } \\
\text { development of } \\
\text { depression }\end{array}$} & \multirow{5}{*}{$\begin{array}{l}\text { Psychometric } \\
\text { Zung self-rating } \\
\text { depression scale }\end{array}$} & The level of expression of depressive symptoms: & \\
\hline & & no depressive symptoms, a state without depression (up to 49 points) & 1 \\
\hline & & mild depression of situational or neurotic origin (50-59 points) & 2 \\
\hline & & subdepressive state (60-69 points) & 3 \\
\hline & & true depression (over 70 points) & 4 \\
\hline
\end{tabular}


calculate the integrated indicator of dynamic changes in mental health of the individual (IIDCMH):

$$
\mathrm{IIDCMH}=\frac{\text { IIAMS }_{1}-\text { IIAMS }_{2}}{\text { IIAMS }_{1}} \times 100 \%
$$

where IIAMS ${ }_{1}$ and IIAMS ${ }_{2}$ - integrated indicators of assessment of the mental state of an individual during different periods of observation (for example, at the beginning and end of the school year, before and after the use of psychoprophylactic and psychohygienic methods of mental correction, etc.).

It should be noted that re-examination should usually be carried out either at the beginning of the next school year, if pupils belong to the category with minimal risk of prenosological changes in mental health, or after the use of psychoprophylactic and psychohygienic methods to determine their effectiveness. Favorable course of mental, psychophysiological and socio-psychological adaptation without the risk of prenosological abnormalities in the mental state is considered in the case if the IIDCMH has a positive or zero value. As an effective application of psychoprophylactic and psychocorrectional methods is determined if the calculated indicators are at least $+5-10 \%$.

\section{DISCUSSION}

Timely detection of prenosological conditions and their adequate correction at the moment is undoubtedly one of the most effective ways to preserve and strengthen the mental health of young women and young men $[1,4,5,15,18]$. Moreover, the data obtained in recent years of research indicate that the prevalence of various prenosological changes in the mental health of modern youth should be considered high enough and marked by a significant variety of their clinically defined manifestations, which include in its structure subthreshold mental and behavioral disorders, early dysfunctional states of psychopathological, neurotic or somatovegetative nature, certain deviations from the average norm [15]. It is undeniable that the formation of prenosological changes is clearly related to the influence of factors such as social living conditions, level of educational adaptation, characteristics of psychophysiological functions and personality traits [16].

Currently, scientists have developed various methods to determine prenosological changes in health in general and mental health in particular, namely methods: screening-testing of health of school-age pupils, screening-assessment of the introduction of health-promoting innovations in educational institutions of various profiles, clinically defined mental health monitoring [3, 4, 17-20]. Each of them has undeniable advantages and prospects for further application, but also, unfortunately, specific disadvantages. Thus, the problem of developing a single generalized in nature and unified in content methodological approach aimed at assessing mental health, which allows for constant, prolonged monitoring of the mental development of children, adolescents and young people, is extremely relevant. That is why the method of screening the degree of risk of prenosological changes in the mental health of school-age pupils, developed, is a completely psychohygienic technology, which lacks a number of methodological limitations inherent in previous approaches, and has significant prospects for widespread use in context formation of an effective public health system.

\section{CONCLUSIONS}

1. The method of screening the degree of risk of prenosological changes in the mental health of school-age pupils, which is designed to determine the degree of expression of neuroticism, state, trait and school anxiety, emotional burnout, aggression and depression. Next, the obtained data are evaluated in standardized points, which are used to calculate: the integrated indicator of mental state and the integrated indicator of dynamic changes in the mental health of young women and young men, on the basis of which the surveyed person should be classified into groups with minimum (from 1.00 to 1.75 points), low (1.76 to 2.50 points), moderate (2.51 to 3.25 points) or high ( 2.26 to 4.00 points) risk of mental disorders health of prenosological content, as well as to substantiate the conclusion about the nature of changes in the leading correlates of mental health in the dynamics of a certain period of time.

2. The proposed method, which is based on the study of the most significant, criterion from a social and educational point of view, personality traits of pupils and determine the degree of risk of prenosological changes in mental health and the formation of individual manifestations of mental pathology, promotes early and adequate carrying out of appropriate psychoprophylactic and psychocorrectional activity, which leads to the improvement of the mental health of young women and young men.

\section{REFERENCES}

1. MorozV.M., MakarovS.Yu., Serebrennikova O. A., Serheta I.V. Navchalnyi stres ta psykhofiziolohichni kryterii otsinky adaptatsiinykh mozhlyvostei orhanizmu studentiv zakladiv vyshchoi medychnoi osvity [Educational stress and psychophysiological criteria for assessing the adaptive capacity of the body of students of higher medical education]. Vinnytsya: TOV «TVORY». 2020. (in Ukrainian).

2. Serheta I.V., BardovV. H., Drezhenkova I. L., Panchuk 0. Yu. Hihiienichni normatyvy rukhovoi aktyvnosti studentiv zakladiv vyshchoi medychnoi osvity ta shliakhy yii optymizatsii [Hygienic standards of motor activity of students of higher medical education institutions and ways of its optimization]. Vinnytsya: TOV «TVORY». 2020. (in Ukrainian).

3. Serheta I. V., Panchuk 0. Yu., Yavorovskyi 0. P. Hygienic diagnostics of professional suitability of students of medical education institutions (on the example of dental specialties) [Hygienic diagnostics of professional suitability of students of medical education institutions (on the example of dental specialties)]. Vinnytsya: TOV «TVORY». 2020. (in Ukrainian).

4. Tymoshchuk 0. V., Polka N. S., Serheta I. V. Naukovi osnovy kompleksnoi hihiienichnoi otsinky yakosti zhyttia ta adaptatsiinykh mozhlyvostei suchasnoi uchnivskoi i studentskoi molodi [Scientific bases of complex hygienic assessment of quality of life and adaptive possibilities of modern pupil and student youth]. Vinnytsya: TOV «TVORY». 2020. (in Ukrainian). 
5. Aherne D., Farrant R., Hickey L. et al. Mindfulness based stress reduction for medical students: optimizing student satisfaction and engagement. BMC Medical Education. 2016;16(1):209.

6. Kumar Pandey A. L. Pandey B. Neurophysiology of Social Conduct and Impact of Adverse Exposures. Avicenna J. Neuro Psycho Physiology. 2017;4(1): e12452. doi: 10.5812/ajnpp.12452.

7. Rasheed F. A., Naqvi A. A., Ahmad R. et al. Academic Stress and Prevalence of Stress-Related Self-Medication among Undergraduate Female Students of Health and Non-Health Cluster Colleges of a Public Sector University in Dammam. J. Pharm Bioallied Sci. 2017;9(4):251-8.

8. Woodman D. Researching Ordinary Young People in a Changing World: The Sociology of Generations and the Missing Middle in Youth Research. Sociological Research Online. 2013;18(1):7.

9. Higuchi D., Echigo A. Characteristics of coping strategies and the relationships between coping strategies and stress reactions in physical therapy students during clinical practice. Journal of physical therapy science, 2016;28(10):2867-70.

10. Kötter T., Niebuhr F. Resource-oriented coaching for reduction of examination-related stress in medical students: an exploratory randomized controlled trial. Advances in Medical Education and Practice. 2016;7:497.

11. Prakticheskaya psihodiagnostika. Metodiki i testy [Practical psychodiagnostics. Techniques and tests]. Pod red. D. Ya. Rajgorodskogo. Samara: Izdatel'skij dom “Bahrah-M", 2011; 667. (in Russian).

12. Antomonov M. Yu. Matematicheskaya obrabotka i analiz medikobiologicheskih dannih [Mathematical processing and analysis of medical and biological data]. 2nd ed.. Kyiv: MIC "Medinform". 2018. (in Russian).

13. Kuchma V. R., Suhareva L. M., Rapoport I. K. et al. Organizaciya medicinskoj profilaktiki v obshcheobrazovatel'nyh uchrezhdeniyah [Organization of medical prevention in educational institutions]. Moscow. 2006. (in Russian).

14. Baranov A. A., Kuchma V. R., Suhareva L. M et al. Sovershenstvovanie medicinskogo obsluzhivaniya podrostkov starshego vozrasta i optimizaciya uslovij obucheniya [Improving health care for older adolescents and optimizing learning environments]. Moscow. 2005. (in Russian).

15. Ponomarenko I. I. Donozologicheskaya diagnostika psihicheskogo sostoyaniya detej nekotoryh regionov strany [Prenosological diagnosis of the mental state of children in some regions of the country]. Aktual'nye voprosy psihogigieny i ohrany psihicheskogo zdorov'ya detej i podrostkov. Moscow. 2007; 176-7. (in Russian).

16. Rabotkin 0. S. Optimizaciya diagnostiki pogranichnyh psihicheskih rasstrojstv u yunoshej doprizyvnogo i prizyvnogo vozrasta [Optimization of diagnosis of borderline mental disorders in young men of preconscription and conscription age]. Problemy social'noj gigieny, zdravoohraneniya i istorii mediciny. 2003; 2: 34-6 (in Russian).

17. Vodolazhs'kij M. L., Merkulova T. V. Skrining-ocinka stanu zdorov'ya shkolyariv [Screening-assessment of health of pupils]. Gigienichni ta social'no-psihologichni aspekti monitoringu zdorov'ya shkolyariv. Kharkiv: IOZDP AMNU, 2006; 38-9. (in Ukrainian).

18. Danilenko G. M. Kompleksna gigienichna skrining-ocinka zdorov'ya ditej v umovah navchal'nogo zakladu [Comprehensive hygienic screeningassessment of children's health in the educational institution]. Aktual'ni pitannya gigieni ta ekologichnoï bezpeki Ukrayni (Pershi marzeevs'ki chitannya). K., 2005:200-201. (in Ukrainian).
19. Makarov S. Y., Stoyan N. V., Serheta I. V. et al. Peculiarities of the interaction of the indicators of psychophysiological adaptation of modern students in the context of the effective monitoring of individual health of young women and young men. Wiadomosci lekarskie. 2019; 72 (5 cz 2):1053-8.

20. Tekliuk R.V., Serheta I.V., Serebrennikova 0. A. Health-related behaviour in adolescents who have received basic instruction in health promotion. Wiadomosci lekarskie. 2019;72(1):12-16.

The article was carried out within the framework of the research works: "Development of modern methods of assessment and forecasting the health of children, adolescents and young women and men and the scientific substantiation of the psychophysiological and psychohygienic correction of the functional state, personality traits, adaptive capacity and professional suitability of pupils and students" (state registration number 0110U001749) and "Physiological and hygienic assessment of the peculiarities of adaptation of children, adolescents and youth to the study conditions in modern educational institutions and the scientific basis of university hygiene: career guidance, problems of implementing health technologies and creating a preventive educational environment" (state registration number 0116U000038).

\section{ORCID and contributionship:}

Ihor V. Serheta: 0000-0002-4439-3833 A, C, E, F

Olha Yu. Bratkova: 0000-0003-3968-2195 A, B, D, F

Oksana V. Dyakova: 0000-0003-4071-3550 C, E, F

Oksana B. Dudarenko: 0000-0002-3848-6283 D,E

Inna L. Drezhenkova: 0000-0002-6794-2516 ${ }^{B, D, E}$

Larysa M. Vakolyuk: 0000-0003-0073-3477 C, F

Tetiana V. Lobastova: 0000-0002-4480-5957 D, E

\section{Conflict of interest:}

The Authors declare no conflict of interest.

\section{CORRESPONDING AUTHOR Ihor V. Serheta \\ National Pirogov Memorial Medical University \\ 56 Pirogov str., ,21018 Vinnytsia, Ukraine \\ tel. +380501807005 \\ e-mail:serheta@gmail.com}

Received: 07.12 .2020

Accepted: 01.04 .2021
A - Work concept and design, B - Data collection and analysis, C - Responsibility for statistical analysis, D -Writing the article, $\mathbf{E}$-Critical review, $\mathbf{F}$ - Final approval of the article 